\title{
The Economics of Residential Solar Panel Installations for Customers on Tiered Rate Plans
}

\author{
Prashanth U. Nyer, John B. Broughton, Candace E. Ybarra \\ Argyros School of Business \& Economics, Chapman University, Orange, CA, USA \\ Email: nyer@chapman.edu, broughto@chapman.edu,cybarra@chapman.edu
}

How to cite this paper: Nyer, P.U., Broughton, J.B. and Ybarra, C.E. (2019) The Economics of Residential Solar Panel Installations for Customers on Tiered Rate Plans. Open Journal of Business and Management, 7, 1999-2008.

https://doi.org/10.4236/ojbm.2019.74137

Received: September 21, 2019

Accepted: October 19, 2019

Published: October 22, 2019

Copyright ( 2019 by author(s) and Scientific Research Publishing Inc. This work is licensed under the Creative Commons Attribution International License (CC BY 4.0).

http://creativecommons.org/licenses/by/4.0/

\begin{abstract}
This case study uses data from a Southern California Edison residential customer on a grandfathered tiered rate plan to investigate 1) whether it was economically beneficial for the customer to have installed solar panels, and 2) what level of usage offset (the percentage of the customer's annual electricity consumption that is provided by the solar panels) would have resulted in the maximum financial return for the customer. We find that solar panels are an excellent investment for this customer, and that the ideal usage offset for this customer (and others on the tiered rate plans) is 100\%. That is, the savings are maximized when the solar panels produce $100 \%$ of the customers' annual electricity consumption.
\end{abstract}

\section{Keywords}

Solar Panels, Net Metering, Sustainability, Discounted Cash Flow, Present

Value, Tiered Rate, Time of Use, Avoided Electricity Cost, Savings, Energy

\section{Introduction}

In May 2018 the California Energy Commission mandated that starting in 2020, all new homes constructed in the state of California with three or fewer floors be solar powered. The Energy Commission estimated [1] that this mandate would increase the cost of new homes by an average of $\$ 8,400$, but that the reduction in energy expenses would exceed the increase in the mortgage payments by an average of $\$ 35$ per month over the following 30 years. This move is designed to help the state move closer to its goal, stated in Senate Bill 100 [2], of requiring $60 \%$ or more of the state's electricity to come from renewable sources by 2030 , and $100 \%$ by 2045 . Federal and state incentives, and the declining prices of solar 
panels have encouraged an increasing number of residential customers to go solar. According to the latest quarterly update (May 2019) from National Renewable Energy Laboratory [3] 13\% of the single family detached structures in California have solar panels, a number far higher than the $2.7 \%$ for the US as a whole. According to data from Go Solar California, a joint effort between the California Energy Commission and the California Public Utilities Commission, published on their website California Distributed Generation Statistics [4], as of June 30, 2019, over 868,000 residential units in the state had solar energy systems installed for a combined capacity of 4,790 Mega Watts (MW). California is clearly at the forefront of the renewable energy movement.

However, is it in the best financial interest of homeowners to go solar ${ }^{1}$ ? A quick search on the Internet will reveal several websites operated by solar panel installers that include examples of hypothetical households and the savings that these households could enjoy by going solar. That these data come from solar panel installers raises questions about the unbiasedness of the data and the conclusions drawn from them. With that in mind we examine a real household in southern California and use the actual data from that household-hourly solar energy generation, electricity purchases from the grid measured at 15-minute intervals, and monthly and annual electricity utility bills-to calculate exactly how much this household saved by going solar. We also use the data to calculate the ideal usage offset (i.e. the percentage of consumption provided by solar) that would have minimized their overall costs and provided them the best return on their investment. While the analyses are based on data from a single household, we can draw broad conclusions that apply to many households.

\section{The Household}

In April 2017, Ruth Singer and her husband Neal paid Solar360, a local Orange, California based firm, a total of \$12,975 to install 14 LG solar panels and Enphase micro inverters rated at a total of $3.990 \mathrm{~kW} \mathrm{DC}(3.472 \mathrm{~kW} \mathrm{AC})$ and with an estimated annual production of 5,816 kWh. This solar panel array was sized to offset approximately $85 \%$ of the Singer family's $6,900 \mathrm{kWh}$ usage in the previous 12 months. This is approximately equal to $6,814 \mathrm{kWh}$, which is the average annual electricity consumption for residential customers in Orange County, California for 2018 [5]. With an average sized house of approximately 2000 square feet, and a home value within $10 \%$ of the median house price for Orange County, California ( $\$ 721,400$ as reported by Zillow.com), this can be considered a typical home in this market.

\section{The System}

The solar panels were mounted on the west facing roof of the house since the south face was partly shaded by tall trees. The proposal from Solar360 estimated a payback of 7 to 8 years and a rate of return on the cash invested of $14.1 \%$. The ${ }^{1}$ In this paper all references to solar will refer to solar photo-voltaic projects rather than to other technologies such as solar thermal. 
Singers knew that the cost of solar panels would keep falling and that they would be able to get a similar system for a lower cost in the future. But they were also aware that the federal solar tax credit, then at $30 \%$, would be reduced to $26 \%$ in $2020,22 \%$ in 2021 and to $0 \%$ in 2022 and beyond for residential solar energy systems [6]. Moreover, the Singers had read that their utility company, Southern California Edison (SCE), would start implementing a new program to compensate solar customers for the excess electricity that the solar panels made. The program, Net Metering 2.0 (NEM 2.0), would start July 1, 2017 [7] and force customers to switch to a Time of Use (TOU) rate plan $^{2}$ (from their existing tiered rate plan) for installations completed after this cut-off date. However, customers who completed their solar installations prior to this deadline had the option to stay with the grandfathered tiered rate plan for 20 more years. Ruth had done some calculations and, based on her usage pattern, felt more comfortable continuing with her current tiered rate plan. Further she liked the idea of retaining the flexibility to use electricity at any time of the day and pay the same rate, as opposed to being on a TOU plan and feeling compelled to run large appliances only at those times of the day when the rates were low. With the net metering deadline fast approaching, the Singers arranged for their solar panel installation to be completed prior to the end of NEM 1.0. (SCE has provided online resources explaining net metering [7])

Though the solar panel installation cost the Singers $\$ 12,975$, they were able to claim the $30 \%$ federal solar tax credit which reduced their effective upfront cost to $\$ 9,082.50$. Now over two years later Ruth had several Excel spreadsheets filled with data on the hourly production of solar energy (obtained through an app that monitors the solar production in real-time), the purchase of electricity from SCE at 15-minute intervals (available from the SCE website), and the monthly electricity bills. She had even managed to painstakingly calculate what her electricity bill would have been for each billing cycle had she not had solar. Though the idea of going green, reducing her reliance on fossil fuel, and thereby reducing her carbon footprint appealed to Ruth, she was pragmatic and wanted to know if her investment in solar made financial sense; or would she have been better off investing that money in the stock market as one of her colleagues had advised her?

Ruth summarized the data into two tables; Table 1 for the 12 month period starting mid-May 2017, and Table 2 for the 12 month period starting mid-August 2018. SCE bills solar customers in two stages; with a portion of the bill (for expenses not directly related to energy generation and delivery) due each month, and the remainder (for energy generation and delivery related expenses) to be settled at the end of the billing year. Further, California provides utility customers two "Climate Credit" payments each year-one in March and the other in September. To make the billing data easier to understand and comparable across months, Ruth calculated for each billing period the total effective SCE bill amount ${ }^{2} \mathrm{~A}$ tiered rate plan is where the customer pays the same rate for electricity regardless of the time of day. In a TOU plan, the cost of electricity is different at different times of the day. 
Table 1. Year 1.

\begin{tabular}{ccccccc}
\hline $\begin{array}{c}\text { Billing } \\
\text { month } \\
\text { starting }\end{array}$ & $\begin{array}{c}\text { Solar } \\
\text { production } \\
\text { this month } \\
\mathrm{kWh}\end{array}$ & $\begin{array}{c}\text { Energy } \\
\text { consumed } \\
\text { this month } \\
\mathrm{kWh}\end{array}$ & $\begin{array}{c}\text { SCE energy } \\
\text { purchased this } \\
\text { month } \\
\text { (rounded) } \mathrm{kWh}\end{array}$ & $\begin{array}{c}\text { Total } \\
\text { effective } \\
\text { SCE bill for } \\
\text { this month }\end{array}$ & $\begin{array}{c}\text { Estimated SCE } \\
\text { bill for this } \\
\text { month }\end{array}$ & $\begin{array}{c}\text { Avoided SCE } \\
\text { bill for this } \\
\text { month }\end{array}$ \\
\hline May-17 & 642.76 & 378.63 & -264 & $-\$ 38.66$ & $\$ 67.07$ & $\$ 105.73$ \\
Jun-17 & 723.94 & 908.02 & 184 & $\$ 25.29$ & $\$ 193.84$ & $\$ 168.55$ \\
Jul-17 & 650.89 & $1,191.30$ & 540 & $\$ 101.81$ & $\$ 263.23$ & $\$ 161.42$ \\
Aug-17 & 580.93 & $1,047.09$ & 466 & $\$ 84.30$ & $\$ 228.31$ & $\$ 144.01$ \\
Sep-17 & 457.33 & 518.43 & 61 & $\$ 8.88$ & $\$ 99.27$ & $\$ 90.39$ \\
Oct-17 & 364.65 & 611.31 & 247 & $\$ 35.50$ & $\$ 121.80$ & $\$ 86.30$ \\
Nov-17 & 277.02 & 590.36 & 313 & $\$ 49.54$ & $\$ 118.08$ & $\$ 68.54$ \\
Dec-17 & 237.93 & 496.77 & 259 & $\$ 38.52$ & $\$ 96.19$ & $\$ 57.67$ \\
Jan-18 & 343.96 & 501.04 & 157 & $\$ 22.84$ & $\$ 98.71$ & $\$ 75.87$ \\
Feb-18 & 396.01 & 536.62 & 141 & $\$ 20.01$ & $\$ 108.10$ & $\$ 88.09$ \\
Mar-18 & 539.67 & 625.80 & 86 & $\$ 12.44$ & $\$ 130.08$ & $\$ 117.64$ \\
Apr-18 & 620.94 & 687.18 & 66 & $\$ 10.95$ & $\$ 144.59$ & $\$ 133.64$ \\
Total & $\mathbf{5 , 8 3 6 . 0 3}$ & $\mathbf{8 , 0 9 2 . 5 5}$ & 2,256 & $\$ 371.38$ & $\$ 1,669.23$ & $\$ 1,297.85$ \\
\hline
\end{tabular}

Table 2. Year 2.

\begin{tabular}{ccccccc}
\hline $\begin{array}{c}\text { Billing } \\
\text { month } \\
\text { starting }\end{array}$ & $\begin{array}{c}\text { Solar } \\
\text { production } \\
\text { this month } \\
\mathrm{kWh}\end{array}$ & $\begin{array}{c}\text { Energy } \\
\text { consumed } \\
\text { this month } \\
\mathrm{kWh}\end{array}$ & $\begin{array}{c}\text { SCE energy } \\
\text { purchased this } \\
\text { month }(\text { rounded) } \\
\mathrm{kWh}\end{array}$ & $\begin{array}{c}\text { Total } \\
\text { effective }\end{array}$ & $\begin{array}{c}\text { Estimated SCE } \\
\text { bill for this } \\
\text { this month }\end{array}$ & $\begin{array}{c}\text { Avoided SCE } \\
\text { month } \\
\text { bill for this } \\
\text { month }\end{array}$ \\
\hline Aug-18 & 541.09 & $1,367.72$ & 827 & $\$ 169.43$ & $\$ 311.07$ & $\$ 141.64$ \\
Sep-18 & 432.16 & 931.27 & 499 & $\$ 96.17$ & $\$ 201.59$ & $\$ 105.42$ \\
Oct-18 & 359.45 & 601.15 & 242 & $\$ 37.36$ & $\$ 124.13$ & $\$ 86.77$ \\
Nov-18 & 301.52 & 730.85 & 429 & $\$ 79.33$ & $\$ 153.58$ & $\$ 74.25$ \\
Dec-18 & 252.79 & 642.34 & 390 & $\$ 71.04$ & $\$ 132.02$ & $\$ 60.98$ \\
Jan-19 & 285.91 & 621.66 & 336 & $\$ 57.89$ & $\$ 123.79$ & $\$ 65.90$ \\
Feb-19 & 344.68 & 578.88 & 234 & $\$ 37.82$ & $\$ 115.51$ & $\$ 77.69$ \\
Mar-19 & 536.48 & 504.05 & -32 & $-\$ 1.66$ & $\$ 99.38$ & $\$ 101.04$ \\
Apr-19 & 552.43 & 569.45 & 17 & $\$ 6.98$ & $\$ 114.45$ & $\$ 107.47$ \\
May-19 & 576.87 & 499.87 & -77 & $-\$ 10.04$ & $\$ 99.81$ & $\$ 109.85$ \\
Jun-19 & 623.52 & 725.91 & 102 & $\$ 15.97$ & $\$ 147.27$ & $\$ 131.30$ \\
Jul-19 & 614.48 & 1257.39 & 643 & $\$ 131.84$ & $\$ 281.47$ & $\$ 149.63$ \\
Total & $\mathbf{5 , 4 2 1 . 3 8}$ & $\mathbf{9 , 0 3 0 . 5 4}$ & $\mathbf{3 , 6 1 0}$ & $\$ 692.13$ & $\$ 1,904.07$ & $\$ 1,211.94$ \\
\hline
\end{tabular}

which was the sum of how much was payable at the end of the billing month, how much of that month's energy purchase was billed at the end of the year, and the prorated Climate Credit amount for that month (by dividing the climate credit for the year into twelve equal monthly credits). Even though the starting 
months for the two one-year periods are different, they both contain 12 complete months totaling approximately 365 days each.

The first thing that caught Ruth's attention was the drop in solar energy production from 5,836.03 kWh in the first year to $5,421.38 \mathrm{kWh}$ in the second year. While Solar360 guarantees that the drop in solar energy production from year one to year two would be only $2 \%$ (from $5,816 \mathrm{kWh}$ to $5,700 \mathrm{kWh}$ ), Ruth realized that there were many other factors affecting solar energy production, and that the larger number of cloudy days in the second year was probably a major reason for the reduction in production. However, the solar production estimate provided by Solar360 had already taken into account the location of the installation and the historical weather patterns for the area, the angle of the roof, the orientation of the solar panels, and tree cover and other factors that affect solar energy production. Over several years the average annual solar energy produced was expected to match the guaranteed rates.

The LG warranty stated that starting in year two the system would lose only $0.6 \%$ efficiency each year such that in year 25 (at the end of which the system warranty expires) the system would generate $83.6 \%$ of the year one energy. Ruth was not worried about the small decrease in energy production from year to year since she knew that the SCE energy rates would continue to increase each year at a rate equal to or greater than inflation. Consequently, her savings from having solar panels would increase each year thereby compensating for any reduction in solar panel efficiency and inflation [8]. So she considered that a wash.

\section{Discounted Cash Flow}

Over the two 12-month periods Ruth had saved an average of $\$ 1,254.90$ each year on SCE bills. A simple payback period calculation $(\$ 9,082.50 / \$ 1,254.90)$ yielded a value of 7.24 years-in line with what was stated in Solar360's proposal. However, Ruth wanted to do a more meaningful analysis which would take into consideration the time value of money and so she decided to do a Discounted Cash Flow (DCF) analysis [9]. Two installers had offered Ruth 20-year, zero-down loans at $5.50 \%$ while her credit union offered her a $5 \%$ home improvement loan to finance the solar upgrade. Eventually Ruth decided to pay cash. Unsure of the appropriate discount rate to use for her analysis, she decided to use a range of discount rates from $1 \%$ to $10 \%$. Ruth felt confident that a range this broad would include the most theoretically appropriate rate. Her neighbor, who is a financial consultant, advised her that a rate at the low end of her range would be most appropriate since the cash flows from her investment in solar would be likely to have low or even zero correlation with the cash flows on her other investments. Table 3 summarizes the results of the DCF analyses with discount rates of $3 \%, 6 \%$ and $9 \%$ and assuming end-of-year cash flows (the annual avoided electricity costs) of $\$ 1,254.90$ every year for 20 years, 25 years (the warranty period for the panels) and 30 years. Most experts, including the California Energy Commission, estimate solar panels will last well beyond their warrantied life [1]. 
Table 3. Discounted cash flow analyses. (Present value of avoided electricity costs at various discount rates).

\begin{tabular}{ccccc}
\hline \multirow{2}{*}{ Assumed Life } & \multicolumn{2}{c}{ Net Present Value of avoided SCE costs at discount rate $=$} & \multirow{2}{*}{ IRR } \\
\cline { 2 - 4 } & $3.0 \%$ & $6.0 \%$ & $9.0 \%$ & \\
\hline 20 years & $\$ 18,669.74$ & $\$ 14,393.60$ & $\$ 11,455.41$ & $12.51 \%$ \\
25 years & $\$ 21,851.76$ & $\$ 16,041.83$ & $\$ 12,326.36$ & $13.19 \%$ \\
30 years & $\$ 24,596.59$ & $\$ 17,273.49$ & $\$ 12,892.41$ & $13.51 \%$ \\
\hline
\end{tabular}

As shown in Table 3, over 25 years, a 6\% discount rate would yield a present value of the avoided electricity costs of $\$ 16,041.83$, well above her initial cash outlay of $\$ 9,082.50$. In fact, at this discount rate, the present value of the cash flows exceeds the initial outlay of $\$ 9,082.50$ part-way through the $10^{\text {th }}$ year. Thus, if Ruth's solar panels worked for just ten years, she would come out ahead. Even with a discount rate of $9 \%$, and even if the panels lasted only 20 years, Ruth would have a present value of the avoided electricity costs in excess of the $\$ 9,082.50$ that she paid for the solar panels.

A colleague of Ruth had once told her that solar panels were not worth it and that she would be better off putting her money in the stock market. To test this claim she calculated the discount rate that would result in the present value of 25 years of cash flows of $\$ 1,254.90$ (the avoided annual electricity costs) to become exactly $\$ 9,082.50$. This is known as the Internal Rate of Return (IRR) and she re-did the analyses for cash flows over 20 years and over 30 years. Her findings are shown in Table 3 under IRR. For a panel life of 25 years (the warrantied life of the panels) the IRR was $13.19 \%$. Even if the panels lasted only 20 years the IRR is still a very healthy $12.51 \%$. Considering that the stock market (S \& P 500) returns are much more volatile and provide inflation adjusted returns of $7 \%$ to $8 \%$ on an average, Ruth's investment in the solar panels looks like a very good one.

\section{Ideal Usage Offset}

Another issue that Ruth wanted to investigate was whether she had installed the right number of panels. Most solar panel installers advised her to have a usage offset of $70 \%$ to $85 \%$, meaning having enough panels to produce $70 \%$ to $85 \%$ of the annual energy consumption. SCE usually limits customers to systems that have at most $120 \%$ usage offset of the expected annual usage. (Customers can get permits for larger solar panel arrays by promising to increase electricity usage over current levels.) In residential installations factors such as aesthetic considerations (for example not wanting solar panels on the street-facing roof), availability of obstruction-free roof space on south and west facing roof planes, overhead powerlines, and shade from trees and adjacent buildings limit the number of solar panels that can be installed. Ruth's $3.990 \mathrm{~kW}$ DC system was designed to offset roughly $85 \%$ of her previous year's electricity consumption $(6,900 \mathrm{kWh})$. However, her electricity consumption increased substantially soon after the solar 
panels were installed because Ruth became pregnant with her first child and decided to take up a work assignment where she could work exclusively from home. Thus, in year 1 (Table 1 ) her consumption rose to approximately 8,093 $\mathrm{kWh}$ resulting in a solar usage offset of only $72.12 \%$. In year 2 (Table 2 ) Ruth's electricity consumption increased even more (to approximately 9,031 kWh) with the arrival of the new baby, and this combined with the lower solar production in the second year, resulted in a usage offset of only $60.03 \%$. Ruth wanted to determine what usage offset percentage would have maximized her savings.

Ruth's 14-panel system (each with its own micro-inverter) cost her $\$ 9,082.50$ after the federal solar tax credit of $30 \%$ for an average of $\$ 648.75$ per panel. After examining the various quotes provided to her by her installer and other competitors, she estimated that each additional solar panel could have been obtained at approximately $98 \%$ of the cost of the last installed panel. Thus the $15^{\text {th }}$ panel would have cost her only $\$ 635.78(\$ 648.75 \times 0.98)$ more, while the $16^{\text {th }}$ panel would have cost even less-just $\$ 623.06(\$ 635.78 \times 0.98)$, and so on. Table 4 shows the estimated cost of the solar panel installations (after the federal tax credit) for different numbers of panels.

Ruth made the reasonable assumption that the solar production would scale linearly with additional solar panels (if all panels were installed on the same roof plane with equal sun exposure.) Ruth then estimated her effective SCE cost of electricity each year if she had solar panel arrays of different sizes, and her estimated effective SCE cost of electricity each year if she had no solar panels. She

Table 4. The effect of increasing usage offset on customer's net savings.

\begin{tabular}{|c|c|c|c|c|c|c|c|c|c|c|c|}
\hline \multirow[t]{2}{*}{$\begin{array}{l}\text { Number } \\
\text { of panels }\end{array}$} & \multirow{2}{*}{$\begin{array}{l}\text { Estimated } \\
\text { panel cost } \\
\text { after Federal } \\
\text { credit }\end{array}$} & \multirow{2}{*}{$\begin{array}{l}\text { Annual solar } \\
\text { energy } \\
1 \text { produced } \\
(\mathrm{kWh})\end{array}$} & \multirow{2}{*}{$\begin{array}{l}\text { Annual } \\
\text { energy } \\
\text { consumed } \\
(\mathrm{kWh})\end{array}$} & \multirow{2}{*}{$\begin{array}{l}\text { Annual SCE } \\
\text { energy } \\
\text { purchased } \\
(\mathrm{kWh})\end{array}$} & \multirow{2}{*}{$\begin{array}{l}\text { Annual } \\
\text { SCE } \\
\text { effective } \\
\text { cost }\end{array}$} & \multirow{2}{*}{$\begin{array}{l}\text { Annual } \\
\text { SCE cost } \\
\text { without } \\
\text { panels }\end{array}$} & \multirow[t]{2}{*}{$\begin{array}{l}\text { Annual } \\
\text { SCE costs } \\
\text { avoided }\end{array}$} & \multirow[t]{2}{*}{$\begin{array}{l}\text { Usage Offset } \\
\text { Percentage }\end{array}$} & \multicolumn{3}{|c|}{$\begin{array}{c}\text { Present value of avoided SCE costs } \\
\text { less cost of solar panels. Discount } \\
\text { rate }=\end{array}$} \\
\hline & & & & & & & & & $3 \%$ & $6.0 \%$ & $9.0 \%$ \\
\hline 14 & $\$ 9,082.50$ & $5,421.38$ & $9,030.49$ & 3,609 & $\$ 685.84$ & $\$ 1,895.86$ & $\$ 1,210.02$ & $60.03 \%$ & $\$ 11,987.76$ & $\$ 6,385.62$ & $\$ 2,803.02$ \\
\hline 15 & $\$ 9,718.28$ & $5,808.62$ & $9,030.49$ & 3,222 & $\$ 610.42$ & $\$ 1,895.86$ & $\$ 1,285.44$ & $64.32 \%$ & $\$ 12,665.28$ & $\$ 6,713.96$ & $\$ 2,908.06$ \\
\hline 16 & $\$ 10,341.33$ & $6,195.86$ & $9,030.49$ & 2,835 & $\$ 533.48$ & $\$ 1,895.86$ & $\$ 1,362.38$ & $68.61 \%$ & $\$ 13,381.99$ & $\$ 7,074.45$ & $\$ 3,040.75$ \\
\hline 17 & $\$ 10,951.93$ & $6,583.10$ & $9,030.49$ & 2,446 & $\$ 454.10$ & $\$ 1,895.86$ & $\$ 1,441.76$ & $72.90 \%$ & $\$ 14,153.65$ & $\$ 7,478.60$ & $\$ 3,209.87$ \\
\hline 18 & $\$ 11,550.32$ & $6,970.35$ & $9,030.49$ & 2,059 & $\$ 374.34$ & $\$ 1,895.86$ & $\$ 1,521.52$ & $77.19 \%$ & $\$ 14,944.13$ & $\$ 7,899.81$ & $\$ 3,394.93$ \\
\hline 19 & $\$ 12,136.74$ & $7,357.59$ & $9,030.49$ & 1,674 & $\$ 294.84$ & $\$ 1,895.86$ & $\$ 1,601.02$ & $81.47 \%$ & $\$ 15,742.06$ & $\$ 8,329.67$ & $\$ 3,589.41$ \\
\hline 20 & $\$ 12,711.43$ & $7,744.83$ & $9,030.49$ & 1,285 & $\$ 219.30$ & $\$ 1,895.86$ & $\$ 1,676.56$ & $85.76 \%$ & $\$ 16,482.76$ & $\$ 8,720.64$ & $\$ 3,756.72$ \\
\hline 21 & $\$ 13,274.62$ & $8,132.07$ & $9,030.49$ & 896 & $\$ 147.75$ & $\$ 1,895.86$ & $\$ 1,748.11$ & $90.05 \%$ & $\$ 17,165.47$ & $\$ 9,072.09$ & $\$ 3,896.33$ \\
\hline 22 & $\$ 13,826.56$ & $8,519.31$ & $9,030.49$ & 510 & $\$ 78.78$ & $\$ 1,895.86$ & $\$ 1,817.08$ & $94.34 \%$ & $\$ 17,814.53$ & $\$ 9,401.82$ & $\$ 4,021.86$ \\
\hline 23 & $\$ 14,367.45$ & $8,906.55$ & $9,030.49$ & 125 & $\$ 10.61$ & $\$ 1,895.86$ & $\$ 1,885.25$ & $98.63 \%$ & $\$ 18,460.69$ & $\$ 9,732.37$ & $\$ 4,150.57$ \\
\hline 24 & $\$ 14,897.53$ & $9,293.79$ & $9,030.49$ & -261 & $-\$ 13.01$ & $\$ 1,895.86$ & $\$ 1,908.87$ & $102.92 \%$ & $\$ 18,341.91$ & $\$ 9,504.24$ & $\$ 3,852.50$ \\
\hline 25 & $\$ 15,417.00$ & $9,681.04$ & $9,030.49$ & -652 & $-\$ 31.89$ & $\$ 1,895.86$ & $\$ 1,927.75$ & $107.20 \%$ & $\$ 18,151.19$ & $\$ 9,226.11$ & $\$ 3,518.48$ \\
\hline 26 & $\$ 15,926.09$ & $10,068.28$ & $9,030.49$ & -1037 & $-\$ 47.30$ & $\$ 1,895.86$ & $\$ 1,943.16$ & $111.49 \%$ & $\$ 17,910.45$ & $\$ 8,914.02$ & $\$ 3,160.76$ \\
\hline 27 & $\$ 16,424.99$ & $10,455.52$ & $9,030.49$ & $-1,425$ & $-\$ 61.73$ & $\$ 1,895.86$ & $\$ 1,957.59$ & $115.78 \%$ & $\$ 17,662.81$ & $\$ 8,599.58$ & $\$ 2,803.59$ \\
\hline
\end{tabular}


was then able to calculate her avoided SCE payments each year for solar panel arrays of various sizes. By calculating the present value of the avoided SCE payments for 25 years (the length of the system warranty) and by subtracting the cost of the solar panel system, she was able to calculate her effective savings by having solar panel arrays of various sizes (see Table 4). The calculation shown in Table 4 was repeated using discount rates of $1 \%$ all the way up to $11 \%$, and with 25 and 20 years of SCE avoided payments. The calculations were also done on Ruth's year 1 and year 2 data. In all cases the pattern of the findings was the same and so we have only shown the calculations for the year 2 data, with 25 year of SCE avoided payments and with discount rates of 3\%, 6\% and $9 \%$.

As the size of the solar panel array increases, its cost increases. At the same time, as the solar production increases, less energy is being purchased from SCE and the avoided SCE costs increases. The difference between the present value of the avoided SCE costs (over 25 years) and the cost of the solar panels (after the federal tax credit) is the customer's savings. What is clear from Table 4 is that the net savings to the customer increase as the usage offset increases from the customer's current $60 \%$ until the usage offset becomes $100 \%$ and then decreases as the usage offset exceeds $100 \%$. These findings are robust and stay the same regardless of the discount rate applied, and whether the life of the solar panel array is assumed to be 25 years or 20 years. The broad findings stay the same even when the customer's first year data were used.

The decrease in the customer's savings that occurs as the usage offset exceeds $100 \%$ is due to how SCE calculates the Net Surplus Compensation for the surplus energy produced by a customer at the end of the billing year at the paltry wholesale price rate (which was $\$ 0.04908$ per $\mathrm{kWh}$ for the billing year ending May 2018) which is much lower than the retail rate paid by customers. Thus, for customers like Ruth, who are on a tiered rate plan, it doesn't pay to have an over-sized system that produces far more energy than what the customer will use in a year.

\section{Conclusions}

In hindsight, Ruth's system is woefully undersized, and she should have installed many more solar panels. Expanding her solar array now with additional panels would force Ruth out of NEM 1.0 and her current tiered rate plan, and Ruth does not wish to do that. Even with her under-sized system she has been saving a lot of money. The bottom-line findings of this analysis for NEM 1.0 customers on a tiered rate plan are that a system with close to $100 \%$ usage offset will provide the greatest net savings. The situation for customers who are on a TOU plan will be more complicated and the ideal usage offset will depend on when during the day the bulk of their energy usage happens, relative to when the solar energy is produced, and when the peak rates are charged. In general, the ideal usage offset level will be lower if the customer can shift most of their discretionary energy use (such as doing the laundry, baking, charging electric vehicles, run- 
ning the pool pump) to times of the day when the rates are at the lowest level.

The conclusion one can draw here is that customers can get the lowest cost on electricity if their annual usage offset is $100 \%$ or in other words if their solar panel array is sized to produce $100 \%$ of their annual consumption. Customers like Ruth may have a hard time forecasting their energy demand in the future; changes in the family structure, hours spent away from home, ownership of electric vehicles and other high Wattage electrical appliances, expansion of the home, and changing weather patterns could all influence a family's energy consumption. For a young family like Ruth's, electricity consumption can be expected to increase in the years to come as she has additional children, her children grow up, her household income increases [10], or she buys one or more electric vehicles. Basic economic theory suggests that when prices fall the quantity demanded increases. Thus, solar customers who see their electricity costs falling as a result of going solar may be likely to consume more electricity-for example by running the air conditioner for more hours during the summer. Given California's mandate to have all new residential units (with three or fewer floors) be solar powered, home builders who are targeting young families may want to consider erring on the side of installing more rather than fewer solar panels-if the building can accommodate it-to keep up with the growing electrical needs of young families [10]. Similarly, customers planning on getting solar panels installed may want to install a larger system if they believe their electricity usage might increase for the next several years.

\section{Limitations and Future Research}

While this study looked at the economic benefits of going solar for a customer on a grandfathered tiered rate plan, it does not examine the financial implications of going solar for customers on time-of-use plans. This is something that deserves to be studied. What would the ideal usage offset percentage be for customers on TOU plans? How much money can TOU customers reasonably save by time shifting a small portion of their electricity consumption? These are issues that deserve to be examined. This study is based on data from one customer, and while the results are generalizable, it would be prudent to do follow-up studies using data from additional customers to validate the findings of this paper.

\section{Conflicts of Interest}

The authors declare no conflicts of interest regarding the publication of this paper.

\section{References}

[1] California Energy Commission (2019) Frequently Asked Questions: 2019 Building Energy Efficiency Standards.

https://ww2.energy.ca.gov/title24/2019standards/documents/Title24_2019_Standar ds_detailed_faq.pdf 
[2] SB-100 California Renewables Portfolio Standard Program: Emissions of Greenhouse Gases (2018).

https://leginfo.legislature.ca.gov/faces/billNavClient.xhtml?bill_id=201720180SB100

[3] Feldman, D. and Margolis, R. (2019). Solar Industry Update Q4 2018/Q1 2019. https://www.nrel.gov/docs/fy19osti/73992.pdf https://doi.org/10.2172/1527335

[4] California Distributed Generation Statistics (2019) Statistics and Charts. https://www.californiadgstats.ca.gov/charts/

[5] California Energy Commission (2019) Electricity Consumption by County. https://ecdms.energy.ca.gov/elecbycounty.aspx

[6] Go Solar California (2019) Tax Credits for Solar System Purchase. https://www.gosolarcalifornia.ca.gov/consumers/taxcredits.php

[7] Southern California Edison (2018) Net Energy Metering: Understanding Your Bill. https://www.sce.com/residential/generating-your-own-power/net-energy-metering/ Understanding-Your-Bill

[8] Echols, E., Karle, M. and Chau, N. (2019). Rate Trends 2009-2019. https://www.cpuc.ca.gov/uploadedFiles/CPUCWebsite/Content/News_Room/NewsU pdates/2019/Cal\%20Advocates\%20Rate\%20Trend\%20Presentation\%20-\%20April\%20 24th\%202019.pdf

[9] Fisher, I. (1930) The Theory of Interest. Macmillan, New York.

[10] Fritzsche, D.J. (1981) An Analysis of Energy Consumption Patterns by Stage of Family Life Cycle. Journal of Marketing Research, 18, 227-232.

https://doi.org/10.1177/002224378101800209 